\title{
Prebiotic effects of inulin extracted from burdock (Arctium lappa) in broilers
}

\author{
Efeito prebiótico da inulina extraída da bardana \\ (Arctium lappa) em frangos de corte
}

\author{
Nair Massumi Itaya', Maria Gabriela Xavier de Oliveira², Mirela Caroline Vilela de Oliveira², \\ Camila Porreta', Márcia Cristina Menão', Ricardo Moraes Borges ${ }^{3}$, José Roberto Machado Cunha

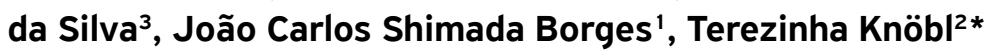

\begin{abstract}
The aim of this study was to evaluate the prebiotic effect of burdock (Arctium lappa) in commercial poultry. Four experiments were conducted to evaluate the performance parameters and the protection after challenge with Salmonella Enteritidis and Salmonella Kedougou, with and without Bifidobacterium probiotic. In two trials, the chickens were fed with flour burdock $1 \%$ during 42 days. In the other two, the chickens were fed with fructan extracted from burdock (inulin), by gavage, at a concentration of $100 \mathrm{mg} / \mathrm{bird}$, during the first three days of life. The results showed that the broilers treated with burdock flour showed underperformed, with less weight gain from the second week, and the worst results in the fattening stage. The treated birds had diarrhea and impaired intestinal integrity. However, the groups treated with the flour had a lower rate of intestinal colonization by Salmonella Kedougou, after challenge. No statistically significant differences were detected in the performance parameters of broilers receiving the inulin, and the morphometric analysis showed no lesions in the intestinal villi. However, there was no protection in the challenge with Salmonella Enteritidis, regardless of association with probiotic. These results demonstrated that the manner of administration has influence on the prebiotic effect of burdock. The burdock flour was administered for 42 days, which may have influenced intestinal mucosal injury. Instead, the inulin was given only in the first three days, which may have been insufficient for protection against Salmonella. New experiments are needed to determine an able formulation for a protective effect, without negative impact on growth, weight gain and feed conversion of the supplemented animals.
\end{abstract}

KEYWORDS: poultry; growth promoters; food additives; broilers; avian salmonellosis.

\begin{abstract}
RESUMO: Este projeto teve por objetivo avaliar o efeito prebiótico da bardana (Arctium lappa) em aves comerciais. Foram realizados quatro experimentos para avaliar os parâmetros zootécnicos e o grau de proteçáo após o desafio com Salmonella Kedougou e Salmonella Enteritidis, com e sem a adição de probióticos à base de Bifidobacterium. Em dois experimentos, as aves receberam a farinha de bardana $1 \%$ na raçáo, durante 42 dias. Nos outros dois, as aves receberam o frutano extraído da bardana (inulina), por gavagem, na concentraçáo de $100 \mathrm{mg} /$ ave, nos três primeiros dias de vida. Os resultados demonstraram que os frangos tratados com farinha de bardana apresentaram desempenho zootécnico inferior ao controle, com menor ganho de peso a partir da segunda semana e piores resultados na fase de engorda. As aves tratadas apresentaram diarreia e comprometimento da integridade intestinal. Em contrapartida, os grupos tratados com a farinha tiveram menor taxa de colonizaçáo intestinal por Salmonella Kedougou, após o desafio. Não foram detectadas diferenças estatisticamente significativas nos parâmetros zootécnicos dos frangos que receberam a inulina, e a análise morfométrica não evidenciou lesôes nas vilosidades intestinais. No entanto, não houve proteção no desafio por Salmonella Enteritidis, independentemente da associação com probiótico. Esses resultados demonstraram que o modo de administração tem influência sobre o efeito prebiótico da bardana. A farinha de bardana foi administrada por 42 dias, o que pode ter causado a lesão da mucosa intestinal. Em contrapartida, a inulina foi administrada apenas nos primeiros três primeiros dias, o que pode ter sido insuficiente para proteção contra Salmonella. Novos experimentos são necessários para determinar uma formulaçáo capaz de promover efeito protetor, sem impacto negativo no crescimento, ganho de peso e conversão alimentar dos animais suplementados.
\end{abstract}

PALAVRAS-CHAVE: avicultura; promotores de crescimento; aditivos alimentares; frangos de corte; salmonelose aviária.

\footnotetext{
'Faculdade de Medicina Veterinária, Complexo Educacional Faculdades Metropolitanas Unidas (FMU) - São Paulo (SP), Brazil.

${ }^{2}$ Faculdade de Medicina Veterinária e Zootecnia, Universidade de São Paulo - São Paulo (SP), Brazil.

${ }^{3}$ Instituto de Ciências Biomédicas, Universidade de São Paulo - São Paulo (SP), Brazil.

*Corresponding author: tknobl@usp.br, veterinaria.tk@gmail.com

Received on: 07/14/2016. Accepted on: 09/25/2017
} 


\section{INTRODUCTION}

Fructans are carbohydrates present in approximately $15 \%$ of angiosperms (CAPRILES, 2009). They can be classified into three main series, according to the different binding patterns: inulins, levan or phlein and graminan-type (ROBERFROID; DELZENNE, 1998). Inulin is a long-chain fructan, composed of 11 to 70 monomers, with $\beta$-D glucopiranosil or $\beta$-D frutofuranosil types of residues, present in foods such as banana, garlic, onion and chicory root (CAPRILES, 2009).

The burdock (Arctium lappa) is an European plant that belonged to the Asteraceae family, presenting a worldwide prevalence, including Brazil. It has been cultivated for many years, mainly in Taiwan and Japan, where the tuberous roots are consumed (HOLETZ et al., 2002). FU (2009) showed the presence of fructans with a mean molecular weight of $3.1 \times$ $10^{3} \mathrm{~g} / \mathrm{mol}$ in the aqueous extract of burdock.

Inulins are considered soluble dietary fibers because there are no digestive enzymes capable of hydrolyzing the bonds of these compounds (ROBERFROID, 2005). Many studies using humans and animal models classify these compounds as functional foods due their nutritional benefits against colon cancer, hypertension, diabetes, inflammatory bowel diseases and dyslipidemia (ARABBI, 2001; GIBSON et al., 2004; ROBERFROID, 2005; KOLIDA; GIBSON, 2007).

The fermentation of fructans stimulates cellular proliferation (cecal hypertrophy), increasing the surface of intestinal absorption. The production of butyric acid stimulates the expression of calbindin, favoring the active transport of calcium (HOLLOWAY et al., 2007). Some organic acids (lactic, acetic, propionic and butyric acids) reduce the intestinal $\mathrm{pH}$ and create an unfavorable environment for colonization by Salmonella spp. (SCHOLZAHRENS; SCHREZENMEIR, 2007). The prebiotic effect of inulin is associated with the growth of bifidobacteria, favoring the gut microbiota that uses inulin and fructooligosaccharides as substrates in the fermentation, inhibiting the development of pathogenic bacteria. Notable beneficial effects of Bifidobacterium include the production of immunostimulating substances and the synthesis of B vitamins (GIBSON et al., 1995; BABU et al., 2012).

The aim of this study was to investigate the prebiotic effects of inulin present in Arctium lappa (burdock) by measuring the performance parameters of broilers after single and associated use (with probiotic Bifidobacterium). We also investigated the integrity of the intestinal mucosa, changes on the gut microbiota and protection against intestinal colonization by Salmonella in broilers experimentally inoculated.

\section{MATERIAL AND METHODS}

The roots of Arctium lappa were washed, conditioned in plastic bags and autoclaved for $20 \mathrm{~min}$. They were then cooled and homogenized in a blender. Half of this homogenate was lyophilized for $18 \mathrm{~h}$ and ground. After processing, the flour (with a low granulometry) was stored under refrigeration $\left( \pm 4^{\circ} \mathrm{C}\right)$.

The other half of the homogenate was subjected to aqueous extraction for 30 minutes at $60^{\circ} \mathrm{C}$ and filtered through cotton cloth. The aqueous extraction process was performed twice. The filtrate from the two extractions was collected and concentrated in a rotoevaporator.

\section{Microbiological Analysis}

Portions of $25 \mathrm{~g}$ of flour and $25 \mathrm{~mL}$ of aqueous extract were analyzed by culture in Brain Heart Infusion (BHI) broth and plating on blood agar, MacConkey agar incubated at $37^{\circ} \mathrm{C}$ for $48 \mathrm{~h}$ and on Sabouraud agar, incubated at $35^{\circ} \mathrm{C}$ for $48 \mathrm{~h}$.

\section{Quantitative analysis of soluble carbohydrates}

The fructans from burdock were extracted as described by POLLOCK; JONES (1979). The burdock meal was boiled in $80 \%$ ethanol $\left(4 \mathrm{~mL} / \mathrm{g}\right.$ of flour), for $5 \mathrm{~min}$ at $80^{\circ} \mathrm{C}$, for inactivation of the enzymes. Then, it was centrifugated at 2,000 rpm for $15 \mathrm{~min}$ at room temperature. The precipitated residues were then re-extracted with $80 \%$ ethanol and centrifugated, as described previously. The precipitated residues were then extracted with distilled water for $30 \mathrm{~min}$ at $60^{\circ} \mathrm{C}$ and vacuum filtered. The supernatants of the three extractions were collected, concentrated to a small volume and taken up in $3.0 \mathrm{~mL}$ of distilled water (total soluble carbohydrate extract). The total fructose content was determined by Anthrone colorimetric modified assay, as described by JERMYN (1956). The dosages were performed in triplicate using Helianthus tuberosus L. inulin (Sigma) as standard.

\section{Quantitative analysis of Fructans}

The extracts were purified on ion exchange columns, using Dowex resins in cationic form (Dowex $50 \times 8-200$ ) and anionic form $(1 \times 8-200)$. After application of a small volume of sample at the top of the column, it was eluted with 20 volumes of distilled water. The eluted sample was then neutralized with ammonia hydroxide and concentrated to dryness, taken up in a small volume of deionized water (18 Megohm.cm). Samples for high performance anion exchange chromatography (HPAEC) analysis were taken to obtain a concentration of $200 \mu \mathrm{g} / \mathrm{mL}$ of total fructose for CarboPac PA-1 column analysis. They were then filtered on nylon membrane $(0.45 \mu \mathrm{m})$ specifically for highperformance liquid chromatography. 


\section{High-Performance Anion Exchange Chromatography}

The sugars were analyzed by the Dionex chromatographic system (model DX-300) on CarboPac PA1 columns. Elution of the carbohydrates was done using a gradient of the eluent A $(150 \mathrm{mM} \mathrm{NaOH})$, eluent B $(500 \mathrm{mM}$ sodium acetate in $150 \mathrm{mM} \mathrm{NaOH}$ ), flow rate of $1 \mathrm{~mL} / \mathrm{min}$ (SHIOMI, 1993). Eluent $\mathrm{B}$ was mixed with eluent A using the following schedule: 0-1 $\mathrm{min}, 25 \mathrm{mM}$; 1-2 $\mathrm{min}, 25-50 \mathrm{mM}$; 2-14 min, 50-500 mM; 14-22 min, $500 \mathrm{mM}$; 22-30 min, $25 \mathrm{mM}$.

Carbohydrates were detected by a pulse amperometric detector (PAD), with potentials applied E1 (540 ms), E2 (100 $\mathrm{ms})$ and E3 (50 ms) 0.10, 0.60, and -0.60 respectively. Level of sensitization was $1,000 \mathrm{nA}$ and paper speed was $0.5 \mathrm{~cm} / \mathrm{min}$.

\section{Efficiency test in animal model}

The experiment was carried out in two phases. In the first one, broilers were supplemented with the burdock meal. In the second phase, broilers were supplemented with extract containing inulin from the tuberous roots of burdock.

\section{First phase: tests with burdock flour $1 \%$}

In the first phase, we evaluated the growth promoter effect in broilers supplemented with $1 \%$ burdock flour, provided in the food during 40 days of breeding (Test 1) and the effect of supplementation on intestinal protection in chickens challenged with Salmonella Kedougou (Test 2). Tests 1 and 2 were performed in the months of January and February 2013.

\section{Test 1: performance of broilers supplemented with burdock flour $1 \%$}

Thirty male broilers of the Ross lineage (divided into three groups of ten birds) were randomly distributed. The birds were housed 1-day-old, fed commercial feed without medicated additives and water ad libitum, for 42 days. The test consisted of three treatments. The $\mathrm{T} 1$ group received a diet supplemented with $1 \%$ of the flour for 42 days and the T2 group received a supplementation with $1 \%$ flour for 42 days plus Bifidobacterium lactis $\left(1 \times 10^{7} \mathrm{CFU} /\right.$ bird $)$ probiotic, by volume of $100 \mu \mathrm{L}$ (gavage) on the seventh day of life. The T3 group received a basal diet (negative control).

Broilers and feed were weighed weekly for weight gain (GP) and feed conversion (CA). At the end of the experiment, the birds were humanly killed for evaluation of enteric microbiota. Fragments of duodenum and cecum were fixed with $10 \%$ formalin, included on paraffin and staining by the eosin-hematoxylin for analysis of integrity of enteric mucosa.

\section{Test 2: Challenge of supplemented broilers (burdock flour 1\%) with \\ S. Kedougou}

Broilers were inoculated experimentally with Salmonella Kedougou (NCTC 12173) resistant to nalidixic acid one week after starting treatment with $1 \%$ burdock meal. One hundred and eighty broilers, male, 1-day old, divided into four groups of ten animals, with two replicates (negative control, positive control, prebiotic and symbiotic) were used. The birds of Groups T1, T2 and T3 were inoculated with $0.1 \mathrm{~mL}$ of broth containing $1.3 \times$ $10^{6} \mathrm{CFU} / \mathrm{mL}$ of $S$. Kedougou orally, through gavage. The T4 group served as the negative control of the test.

The animals were humanly killed seven days after the challenge. The cecum was removed and packed in plastic bags for weighing. One gram of feces from each bird diluted in $9 \mathrm{~mL}$ of $0.1 \%$ peptone water was subjected to analysis according to the methodology described by MEAD et al. (1989) using XLT4 medium containing $100 \mu \mathrm{g}$ of nalidixic acid per $\mathrm{mL}$. After incubation at $37^{\circ} \mathrm{C}$ for $24 \mathrm{~h}$, colonies with characteristic morphology were confirmed by biochemical tests and rapid serum agglutination $\left(\right.$ Probac $\left.^{\oplus}\right)$.

\section{Second phase: tests with inulin extracted from burdock ( $100 \mathrm{mg} / \mathrm{mL})$}

In the second phase, we evaluated the growth promoter effect of aqueous extracts of burdock tuber roots (in the concentration of $100 \mathrm{mg} / \mathrm{bird}$ ) in broiler chickens supplemented by gavage in the first three days of life (Test 3) and the effect of intestinal protection in supplemented broilers challenged with Salmonella Enteritidis (Test 4). These tests were carried out in the months of May and June 2013.

\section{Test 3: performance of broilers supplemented with aqueous extract of burdock}

Sixty broilers of the Ross lineage (divided into three groups of ten birds with two replicates) were randomly distributed. The birds were fed commercial feed without medicated additives and water ad libitum for 42 days. The test consisted of three treatments. The $\mathrm{T} 1$ group received three consecutive doses of aqueous extract of burdock roots by gavage at $100 \mathrm{mg} /$ bird/day. The T2 group was also supplemented with aqueous extract of burdock $(100 \mathrm{mg} / \mathrm{bird})$ and probiotic based on Bifidobacterium lactis $\left(1 \times 10^{7} \mathrm{CFU} / \mathrm{bird}\right)$, by gavage $(100 \mu \mathrm{L})$ in the first three days of life. The $\mathrm{T} 3$ group received a basal diet (negative control).

Animals and feed were weighed weekly for weight gain (GP) and feed conversion (CA). At the end of the experiment, the birds were humanly killed for evaluation of enteric microbiota and integrity of the mucosa. Fragments of intestine 
(duodenum and cecum) were fixed with 10\% formaldehyde, included in paraffin and staining by the eosin-hematoxylin method by subsequent histological and morphometric analysis.

Feces from each bird ( $1 \mathrm{~g}$ ) were subjected to bacteriological analysis for isolation, identification and counting of Enterobacteria. Samples were diluted in LB broth and seeded on MacConkey $37^{\circ} \mathrm{C}$ agar for $24 \mathrm{~h}$. Identification was performed by biochemical tests (Enterokit Probac ${ }^{\oplus}$, Probac do Brasil Produtos Bacteriológicos, São Paulo, São Paulo, Brazil). Isolation of Bifidobacterium was carried out after culture in Bifidobacterium broth and medium selective for Bifidobacterium (DifcoR) after cultivation at $37^{\circ} \mathrm{C}$ for $24-48 \mathrm{~h}$ in anaerobiosis, using anaerobic generator (Anaerobac, Probac do Brasil Produtos Bacteriológicos, São Paulo, São Paulo, Brazil). Identification was confirmed by the Polymerase Chain Reaction (PCR) technique, using the methodology described by KOK et al. (1996).

\section{Test 4: challenge of supplemented broilers (aqueous extract of burdock) with S. Enteritidis}

The birds of Test 4 were inoculated experimentally with Salmonella Enteritidis (SE499) one week after initiation of treatment with aqueous extract of burdock roots (second week of bird life). A total of 80 broiler chickens, 1-day old, were divided into four groups of ten animals, with two replicates (negative control, positive control, prebiotic and symbiotic). The birds of Groups T1, T2 and T3 were inoculated with $0.1 \mathrm{~mL}$ of aqueous extract of burdock in the first three days of life, and challenged in the second week with $1.0 \times 10^{7} \mathrm{CFU} / \mathrm{mL}$ of $S$. Enteritidis, through gavage. The T4 group served as the negative control of the test. The animals were humanly killed seven days post challenge (third week of age). The cecums were removed and packed in plastic bags for weighing. One gram of feces from each bird, diluted in $9 \mathrm{~mL}$ of $0.1 \%$ peptone water, was subjected to analysis according to the methodology described by
MEAD et al. (1989) using XIT4 medium. After incubation at $37^{\circ} \mathrm{C}$ for $24 \mathrm{~h}$, the colonies with characteristic morphology were confirmed by biochemical tests and rapid serum agglutination.

\section{Statistical analysis}

The statistical analysis was performed using Statistical Package for the Social Sciences (SPSS) Base 9.0 software. The groups were compared by a Kruskal-Wallis non-parametric test (significant values - $\mathrm{p}<0.05)$.

This research was approved by the Ethic Committee in the use of animals of the School of Veterinary Medicine and Animal Science of Universidade de São Paulo, under the protocol number 2607/2012.

\section{RESULTS AND DISCUSSION}

The method of producing the burdock flour by lyophilization presented an approximate yield of $230 \mathrm{~g}$ of flour for each $\mathrm{kg}$ of processed tuberous root. The method allowed the production of a product that is easy to administer and free from fungal and bacterial contamination as evidenced by negative culture tests. The product could be easily incorporated into the commercial feed, which acquired a characteristic odor after mixing.

The quantitative analysis of the aqueous extract of tuberous roots of burdock resulting from $906.91 \mathrm{~g}$ of fresh mass presented the concentration of $121.43 \mathrm{mg}$. $\mathrm{mL}-1$ of fructose in a total volume of $450 \mathrm{~mL}$. For comparison, the quantitative analysis of the aqueous extract of the tuber of Helianthus tuberosus was carried out, which resulted in 1,189.99 $\mathrm{g}$ of fresh mass, with $123,34 \mathrm{mg}$. $\mathrm{mL}-1$ of fructose in a total volume of $795 \mathrm{~mL}$. The qualitative HPAEC / PAD analysis on CarboPac PA-1 column of soluble carbohydrates extracted from burdock roots showed a chromatographic profile like that of $H$. tuberosus, but a sizeable proportion of monosaccharides

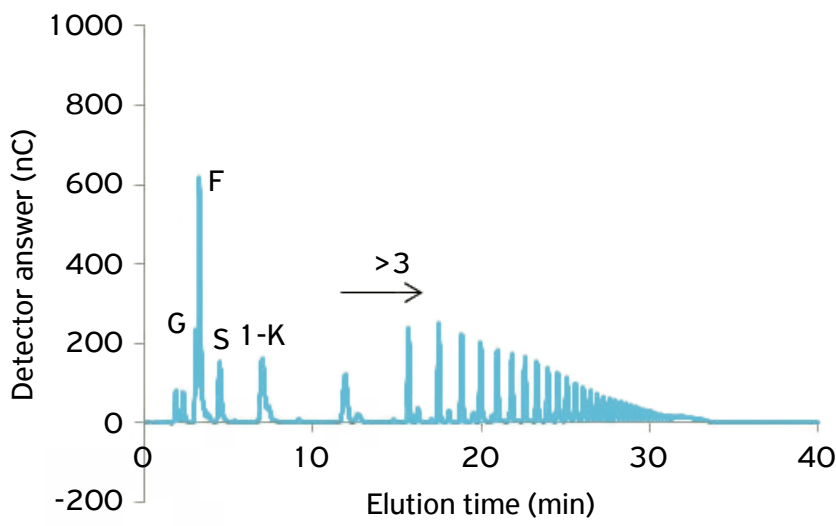

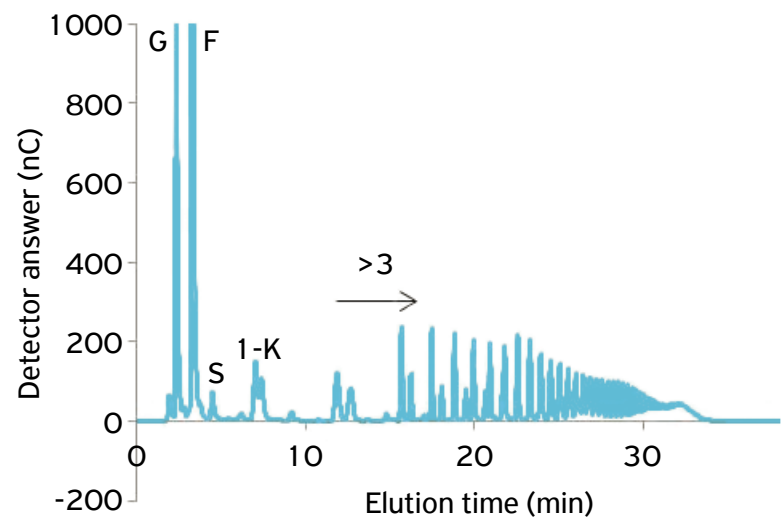
Figure 1. Analysis by HPAEC / PAD in Carbo-Pac PA 1 column of the total soluble carbohydrates of Arctium lappa roots
(a), oligofructans of Helianthus tuberosus as standard (b). G, F, S, 1K time of elution: glucose, fructose, sucrose and 1 -cestose standards, respectively. The remaining peaks were identified by comparison with the elution time of the oligofrutans of $H$. tuberosus. The numerical values refer to the GP of the fructan. Samples containing $200 \mathrm{mg}$ fructose $/ \mathrm{mL}$. 
and the presence of high garlic polysaccharides polymerization (GP) (Fig. 1).

The growth promoting effect of the flour was evaluated in Test 1 . The birds were housed on the first day of life. Mean weight observed was $44 \mathrm{~g}$ for the burdock group (T1), $44 \mathrm{~g}$ for the group treated with burdock + Bifidobacterium (T2) and $46 \mathrm{~g}$ for the negative control (T1). The performance parameters observed are shown in Table 1. There was no mortality in the $\mathrm{T} 1$ and $\mathrm{T} 3$ groups, but in the $\mathrm{T} 2$ group mortality reached $20 \%$, with loss of two birds in the $5^{\text {th }}$ and $6^{\text {th }}$ week of age. The necropsy of these birds revealed ascites, which may have been caused by the elevation of the temperature of the shed, since this experiment was carried out in the summer.

The performance parameters of the treated groups were worse, if compared to the commercial breeding indexes. At the end of the experiment, the feed conversion of broilers treated with burdock flour and burdock + Bifidobacterium were 3.0 and 3.7 , respectively. However, the feed conversion of the control group was also considered high (2.8). Numerous factors may have contributed to this low performance, among which we highlight ventilation and ambience failures, as well as the absence of antibiotic as growth promoters in the food. It is quite likely that the amount of plant fibers present in the initial formulation has contributed to these negative aspects. ZATARI et al. (1990) and PINHEIRO et al. (2002) verified that the amount of fiber resulting from the addition of sunflower meal worsens the feed conversion of chickens at 28 days of age, due to the increase of the digestion rate in the gastrointestinal tract, with a consequent reduction in nutrient availability.

This experiment was carried out in the summer and the hot temperature probably contributed to the loss and shelter of the birds. Apparently, alteration of odor of the ration and a possible alteration of the palatability of the product did not have negative influence on the average consumption of ration, since the $\mathrm{T} 1$ and $\mathrm{T} 2$ groups presented a superior consumption in relation to the control, in some weeks. In this way, the feed conversion was strongly influenced by the lower weight of the treated groups, perceived in the first week after the beginning of the experiment and that increased in the fattening phase (from the fourth to the sixth week), with the worst result observed for the group treated with burdock and Bifidobacterium (T2) (Table 1).

Histological analysis revealed a significant loss of epithelial integrity of gut, with greater damage to the birds of T2 group (Fig. 2). These lesions may be due to the mechanical action caused by the fiber, although it is possible to consider the possibility of an anti-nutritional factor, as in the case of soybeans and white beans. During the experiment, the stool consistency and intestinal transit were altered, increasing the litter humidity of the treated groups T1 and T2. The loss of intestinal villi made it impossible to perform the morphometric examination in this experimental group and certainly contributed to the removal of the animals from the treated groups.

In the challenge of the birds supplemented with burdock meal (Test 2), there was no isolation of Salmonella in the birds of the negative control, which demonstrates that the experimental conditions were adequate. In the positive control, it was possible to recover the agent in 13 from a total of 20 birds (65\% infectivity). The burdock group had a total of $7 / 20$ infected birds, with a protection index of $65 \%$, while the group treated with burdock and Bifidobacterium had a total of 5/20 infected birds, obtaining a protection index of $75 \%$. RISHI et al. (2009) reported that inulin administration in rats can prevent the bacterial translocation

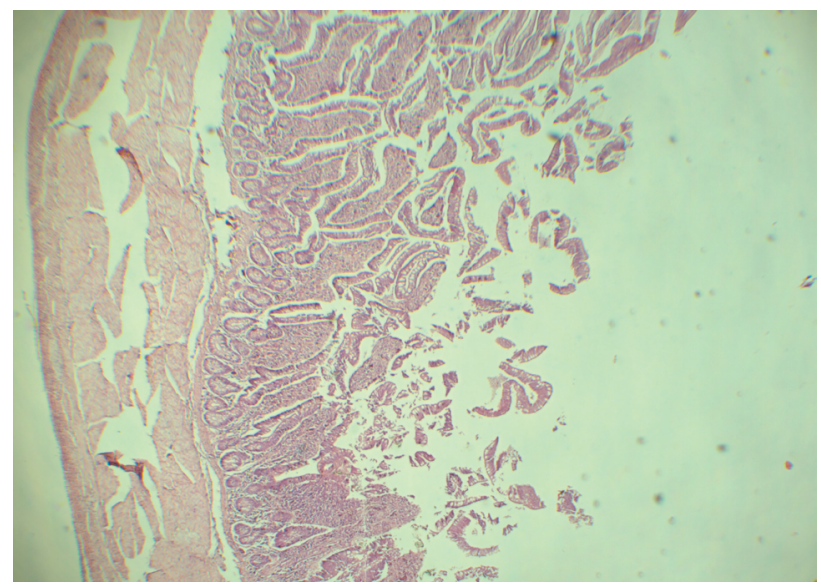

Figure 2. Intestinal epithelium of broiler treated with $1 \%$ burdock meal and Bifidobacterium (Group T2). Hematoxylineosin. Note intense destruction of the intestinal villi.

Table 1. Performance of broilers fed with flour burdock (T1); flour burdock with Bifidobacterium (T2) and negative control (T3): Test 1.

\begin{tabular}{|c|c|c|c|c|c|c|c|c|c|c|}
\hline \multirow{2}{*}{$\begin{array}{l}\text { Age } \\
\text { (weeks) }\end{array}$} & \multicolumn{3}{|c|}{ Weight gain $(\mathrm{g})$} & \multicolumn{3}{|c|}{ Feed intake $(\mathrm{g})$} & \multicolumn{3}{|c|}{ Feed conversion ratio } & \multirow{2}{*}{$P$ value } \\
\hline & $\mathbf{T} 1$ & T2 & T3 & $\mathbf{T} 1$ & T2 & T3 & $\mathrm{T} 1$ & T2 & T3 & \\
\hline 1 & 46.0 & 28.9 & 131.0 & 50.8 & 50.6 & 60.0 & - & - & - & - \\
\hline 2 & 154.0 & 156.0 & 133.0 & 381.0 & 377.0 & 453.0 & 1.08 & 0.96 & 0.99 & 0.873 \\
\hline 3 & 252.0 & 172.0 & 252.3 & 949.0 & $1,035.5$ & 991.0 & 1.48 & 1.46 & 1.87 & 0.560 \\
\hline 4 & 299.6 & 346.0 & 333.0 & $1,024.0$ & $1,136.5$ & 937.9 & 0.93 & 1.08 & 1.26 & 0.560 \\
\hline 5 & 355.0 & 216.4 & 304.0 & $1,160.0$ & $1,152.8$ & $1,160.0$ & 0.88 & 0.89 & 1.00 & 0.873 \\
\hline 6 & 295.0 & 309.0 & 338.0 & $1,224.0$ & $1,260.7$ & $1,110.0$ & 0.65 & 0.76 & 0.83 & 0.560 \\
\hline
\end{tabular}

Means are different $(p<0.05)$ by Kruskal-Wallis non-parametric test. All values were considered not statistically significant. 
process. Besides these properties, BIBAS BONET et al. (2010) found that flour with inulin obtained from the yacon root (Smallanthus sonchifolius), when administered for a prolonged period, increases the number of bifidobacteria and lactobacilli in the large intestine and these microorganisms exert an immunomodulatory effect, causing the elevation of IgA cells, T cells, IL-10 and other cytokines.

The results of the third experiment showed that the administration of inulin at $100 \mathrm{mg} / \mathrm{bird} /$ day did not alter the performance of the animals supplemented, since the difference in weight gain, feed intake and feed conversion parameters of the treated groups showed no significant difference in relation to the control group. The results obtained are shown in Table 2.

Table 2 shows that the weight gain of the T1 group (inulin) was slightly lower than the control group in the six weeks evaluated. However, when inulin was offered in conjunction with the probiotic, there was an improvement in weight gain, with superior results compared to the control group (T3) between the third and fifth week of breeding. On the feed intake, the T1 group (inulin) presented lower consumption in the six weeks evaluated. Table 2 presents the mean feed conversion (AC) results of treated and untreated birds in the two replicates. The mean $\mathrm{AC}$ of the treatments was 1.39 for the $\mathrm{T} 1$ group (inulin), 1.28 for the T2 group (inulin + Bifidobacterium) and 1.45 for the negative control. Considering this average, it is possible to conclude that the best performance can be attributed to the association of inulin and Bifidobacterium, although the difference is not considered statistically significant. These data suggest that the presence of Bifidobacterium altered the enteric microbiota, favoring the growth of the broilers.

The enterobacteria count ranged from $1.4 \times 10^{8}$ to $2.0 \times 10^{7}$ $\mathrm{CFU} / \mathrm{g}$ feces in the T1 group and from $4.0 \times 10^{6}$ to $2.0 \times 10^{7}$ in the $\mathrm{T} 2$ group. The control group presented a lower variation, from $4.9 \times 10^{6}$ to $7.4 \times 10^{6} \mathrm{CFU} / \mathrm{g}$ feces. The presence of Bifidobacterium was detected in all birds of the treated groups and in the control group, when the sample was pre-enriched in broth. Direct culture of the sample in serial dilutions (without enrichment) was negative for all the groups, making quantitative analysis impossible.

Table 2. Performance of broilers fed with extract of inulin (T1), inulin with Bifidobacterium (T2) and negative control (T3): Test 3.

\begin{tabular}{lccccccccccc} 
Age & \multicolumn{3}{c}{ Weight gain $(\mathrm{g})$} & \multicolumn{3}{c}{ Feed intake $(\mathrm{g})$} & \multicolumn{3}{c}{ Feed conversion ratio } \\
\cline { 2 - 11 } (weeks) & T1 & T2 & T3 & T1 & T2 & T3 & T1 & T2 & T3 & P value \\
\hline 1 & 87.7 & 104.9 & 116.0 & 136.9 & 159.8 & 178.9 & 1.55 & 1.52 & 1.53 & 1,000 \\
\hline 2 & 251.9 & 243.9 & 258.5 & 429.4 & 449.4 & 491.25 & 1.69 & 1.83 & 1.90 & 0.5647 \\
\hline 3 & 276.2 & 436.5 & 400.3 & 526.9 & 634.6 & 630.9 & 2.14 & 1.45 & 1.57 & 0.1801 \\
\hline 4 & 384.2 & 525.0 & 516.0 & 703.3 & 790.5 & 877.7 & 1.86 & 1.50 & 1.70 & 0.1801 \\
\hline 5 & 605.0 & 683.7 & 682.9 & 482.4 & 753.5 & 727.4 & 0.79 & 1.11 & 1.06 & 0.1801 \\
\hline 6 & 517.0 & 580.0 & 640.8 & 672.7 & 515.5 & 824.1 & 1.29 & 2.20 & 2.41 & 0.1801 \\
\hline
\end{tabular}

Means are different $(p<0.05)$ by Kruskal-Wallis non-parametric test. All values were considered not statistically significant.

Table 3. Intestinal morphometry of broilers treated with inulin broth (T1), with inulin and Bifidobacterium (T2) and negative control (T3): Test 3.

\begin{tabular}{lcccccc} 
& \multicolumn{2}{c}{ Thickness of cecum mucosa } & \multicolumn{2}{c}{ Thickness of duodenum mucosa } \\
\cline { 2 - 7 } Birds & $\begin{array}{c}\text { Control } \\
\text { T3 }\end{array}$ & $\begin{array}{c}\text { Burdock } \\
\text { T1 }\end{array}$ & $\begin{array}{c}\text { Burdock + } \\
\text { Bífidobacterium } \\
\text { T2 }\end{array}$ & $\begin{array}{c}\text { Control } \\
\text { T3 }\end{array}$ & $\begin{array}{c}\text { Burdock + } \\
\text { Burdock T1 }\end{array}$ & $\begin{array}{c}\text { Bidobacterium } \\
\text { T2 }\end{array}$ \\
\hline 1 & 22.934 & 18.443 & 15.978 & 21.637 & 19.994 & 32.441 \\
\hline 2 & 20.146 & 30.681 & 19.836 & 25.189 & 19.771 & 29.337 \\
\hline 3 & 20.049 & 18.934 & 19.696 & 16.277 & 20.829 & 22.256 \\
\hline 4 & 25.497 & 30.281 & 22.746 & 25.935 & 21.980 & 20.780 \\
\hline 5 & 31.369 & 24.834 & 27.442 & 21.526 & 18.882 & 30.574 \\
\hline 6 & 28.379 & 31.697 & 29.175 & 22.034 & 19.457 & 29.334 \\
\hline 7 & 31.948 & 20.393 & 26.421 & 26.441 & 21.532 & 20.469 \\
\hline 8 & 17.441 & 27.272 & 32.020 & 16.470 & 24.126 & 19.256 \\
\hline 9 & 31.946 & 21.767 & 25.795 & 20.557 & 19.491 & 23.577 \\
\hline 10 & 17.440 & 26.039 & 35.915 & 21.980 & 22.355 & 28.495 \\
\hline Average & 24.715 & 25.034 & 25.502 & 21.805 & 20.842 & 25.652 \\
\hline Standard derivation & 5,912 & 4,975 & 6,085 & 3,508 & 1,643 & 4,864 \\
\hline
\end{tabular}


The results of the morphometric analysis of the groups are shown in Table 3. The difference in the thickness of the cecum and duodenum in treated animals was considered nonsignificant by statistical analysis.

In the fourth experiment, the inulin administration had no negative influence on the development of the animals. The birds presented no diarrhea or other clinical signs. However, the inclusion of inulin in food was not very effective for protection against challenge with Salmonella Enteritidis. A total of 18 birds was positive $S$. Enteritidis after inulin treatment, and 14 birds were positive in the association of inulin and Bifidobacterium, both superior to the positive control (9/20 birds were positive). No birds were positive for $S$. Enteritidis in the negative control.

The resident microbiota exerts influence on intestinal physiology, acting on the transit velocity, rate of enterocyte turnover, enzymatic activity and absorption of nutrients, water and electrolytes. The metabolism of anaerobic bacteria present in the cecum of birds increases the concentration of organic acids, such as butyric acid, exerting a protective effect against the presence of certain pathogens. VERDONK et al. (2005) reinforce the hypothesis that the protective action of prebiotics, as well as resistance to infections, varies according to the type and dose of inulin for each species, and also the virulence of the investigated agent. In this case, there was no protection against $S$. Enteritidis infection with treatment protocol restricted to the first days of breeding.

The increase in the number of infected birds in the fourth experiment, a fact not observed in the $S$. Kedougou assays, may be associated with the adaptation of $S$. Enteritidis serovar to the acidic environment, promoted by the fermentation of the probiotic bacteria. LOUND et al. (2011) carried out an experiment on the acid resistance and temperature of serotypes of Salmonella in dehydrated egg albumin and found that $S$. Enteritidis and $S$. Typhimurium serovars showed higher resistance to effects at $\mathrm{pH}<5$.

Studies with commercial frutoligosaccharides have proposed that its administration may regulate $\operatorname{IgA}$ secretion in young rats, suggesting a more effective treatment to prevent
Salmonella Typhimurium infection in pigs (NAKAMURA et al., 2004). The intestinal lavage content of chickens from the fourth experiment was collected and stored for a future IgA dosage.

\section{CONCLUSION}

Considering the results obtained in the first phase of this study, it was possible to conclude that the addition of burdock flour $1 \%$ increased protection against intestinal colonization by $S$. Kedougou. The protective effect was most evident when administration of burdock was associated with a Bifidobacterium culture. The use of inulin in the form of flour, however, compromised the integrity of the intestinal epithelium, negatively affecting the performance of broilers.

In the second phase of this project, it was possible to observe that the inulin extracted from the burdock has no deleterious effect on the mucosa when administered in the form of aqueous extract. However, this formulation had no protective effect on treated animals and subsequently challenged with Salmonella Enteritidis.

These results demonstrate the potential effect of this fructan as a food additive. On the other hand, the commercial use of this compound in poultry will depend on the suitability and economical viability of the inulin extraction process. Further studies should evaluate the safest and most effective dose and formulation for use in broilers, the influence of this inulin on the performance of broilers, the protective effects against Salmonella spp., as well as the immunomodulatory effect of these compounds.

\section{ACKNOWLEDGEMENTS}

This study was supported by Conselho Nacional de Desenvolvimento Científico e Tecnológico (CNPq 47.83.63/2011.7). We are gratefully to Instituto de Botânica de São Paulo for laboratory support.

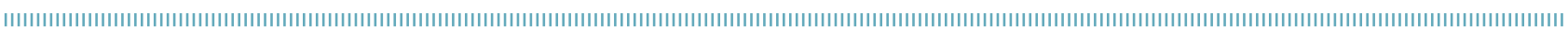

\section{REFERENCES}

ARABBI, P.R.P. Functional foods: General aspects. Journal of Brazilian Society for Food and Nutrition, São Paulo, v.2 1, n. 1, p.87-102, 2001.

BABU, U.S.; SOMMERS, K.; HARRISON, L.M.; BALAN, K.V. Effects of fructooligosaccharide-inulin on Salmonella-killing and inflammatory gene expression in chicken macrophages. Veterinary Immunology and Immunopathology, v.149, p.92-96, 2012.

BIBASBONET, M.E.; MESON, O.; LEBLANC, A.M.; DOGI, C.A.; CHAVES, S.; KORTSARZ, A.; GRAU, A.; PERDIGÓN, G. Prebiotic effect of yacon (Smallanthus sonchifolius) on intestinal mucosa using a mouse model. Food and Agriculture Immunology, v.2 1, p. 175-189, 2010.
CAPRILES, V. Otimização de propriedades nutricionais e sensoriais de produtos à base de amaranto enriquecidos com frutanos, para intervenção em celíacos. 198f. Thesis (Doutorado) - Faculdade de Saúde Pública, Universidade de São Paulo, São Paulo, 2009.

FU, Y.L. Isolation, purification and structural elucidation of a fructan from Arctium lappa. Journal of Medicine Plants Research, v.3, p.171-173, 2009.

GIBSON, G.R.; BEATLY, E.R.; WANG, X.; CUMMINGS, J.H. Selective stimulation of bifidobacteria in the human colon by oligofructose and inulin. Gastroenterology, v.108, p.975-982, 1995. 
GIBSON, G.R.; PROBERT, H.M.; VAN LOO, J.; RASTALL, R.A.; ROBERFROID, M.B. Dietary modulation of the human colonic microbiota: updating the concept of prebiotics. Nutrition Research Rreviews, v.17, n.2, p.259-275, 2004.

HOLETZ, F.B.; PESSINI, G.L.; SANCHES, N.R.; CORTEZ, D.A.; NAKAMURA, C.V.; FILHO, B.P. Screening of some plants used in the Brazilian folk medicine for the treatment of infectious diseases. Memórias do Instituto Oswaldo Cruz, v.97, p.1027$1031,2002$.

HOLLOWAY, L.; MOYNIHAN, S.; ABRAMS, S.A.; KENT, K.; HSU, A.R.; FRIEDLANDER, A.L. Effects of oligofructose-enriched inulin on intestinal absorption of calcium and magnesium and bone turnover markers in postmenopausal women. British Journal of Nutrition, v.97, n.2, p.365-372, 2007.

JERMYN, M.A. A new method for the determination of ketoheoses in presence of aldohexoses. Nature, v.177, p.38-39, 1956.

KOK, R.G.; WAAL, A.; SCHUT, F.; WELLING, G.W.; WEENK, G.; HELLINGWERF, K.J. Specific detection and analysis of a probiotic Bifidobacterium strains in infant feces. Applied Environmental Microbiology, v.62, p.3668-3672, 1996.

KOLIDA S.; GIBSON, G. Prebiotic capacity of inulin-type fructans. Journal of Nutrition, v.137, p.2503S-2506S, 2007.

LOUND, S.; PLEM, L.F.; FAVRE, L.; GENARO, F.; MARTINEZ, L.G.; GIANNUZZI, L. Resistência a ácido e a temperatura de sorotipos de Salmonella em albumina de ovo desidratada. In: Latin American Poultry Congress, 22., 2011 . Avaliable from: <http://pt.engormix.com/MA-avicultura/saude/artigos/ sorotipos-salmonella-albumina-de-ovo-t674/165-pO.htm>. Accessed on: Dec. 242013.

MEAD, G.C.; BARROW, M.H.; HINTON, F.; HUMBERT, F.; IMPEY, C.S.; LAHELLEC, R.W.; MULDER, A.W.; STRAVIC, S.; STERN, N.J. Recommended assay for treatment of chicks to prevent Salmonella colonization by "competitive exclusion. Journal of Food Protection, v.52, n.7, p.500-502, 1989.
NAKAMURA, Y.; NOSAKA, S.; SUZUKI, M.; NAGAFUCHI, S.; TAKAHASHI, T.; YAJIMA, T.; TAKENOUCHI-OHKUBO, N.; IWASE, T.; MORO, I. Dietary fructooligosaccharides up-regulate immunoglobulin a response and polymeric immunoglobulin receptor expression in intestines of infant mice. Clinical Experimental Immunology, v.137, p.52-58, 2004.

PINHEIRO, J.W.; FONSECA, N.A.N.; SILVA, C.A.; CABRERA. L.; BRUNELI, F.A.T.; TAKAHASHI, S.E. Farelo de Girassol na alimentação de frangos de corte em diferentes fases de desenvolvimento. Revista Brasileira de Zootecnia, v.31, p. 1418-1425, 2002.

POLLOCK, C.J.; JONES, T. Seasonal patterns of fructan metabolism in forage grasses. New Phytology, v.83, p. 9-15, 1979.

RISHI, P.; MAVI, S.K.; BHARRHAN, S.; SHUKLA, G.; TEWARI, R. Protective efficacy of probiotic alone or in conjunction with a prebiotic in Salmonella-induced liver damage. FEMS Microbiology Ecology, v.69, p.222-230, 2009.

ROBERFROID, M.B. Introducing inulin-type fructans. Brazilian Journal of Nutrition, v.93, p.S13-S25, 2005.

ROBERFROID, M.B.; Delzenne, N. Dietary fuctans. Annual Review of Nutrition, v.18, p.117-143, 1998.

SCHOLZ-AHRENS, K.; SCHREZENMEIR, J. Inulin and oligofrutose and mineral metabolism: the evidence from animal trials. Journal of Nutrition, v.137, p.2513S-2523S, 2007.

SHIOMI, N. Structure of fructo-polysaccharide (asparagosin) from roots of asparagus (Asparagus officinalis L.). New Phytology, v.123, p.263-270, 1993.

VERDONK, J.M.A.J.; SHIM, S.B.; VAN LEEUWEN, P.; VERSTEGEN, M.W.A. Application of inulin-type fructans in animal feed and pet food. British Journal of Nutrition, v.93, n.S1, p.S125-S138, 2005.

ZATARI, I.M.; SELL, J.L. Sunflower meak as a component of fatsupplemented diets for broiler chickens. Poultry Science, v.69, p.1503-1507, 1990. 